\section{The EU Directive ON FreE Movement - A Challenge FOR THE EUROPEAN WELFARE STATE?}

\section{WOLFGANG OCHEL*}

The EU Directive on Free Movement (Directive) has extended the right of free movement to non-gainfully employed (inactive) Union citizens. At the same time, this group of persons has been given access to the welfare benefits of host countries. Moreover, the right of residence of gainfully employed EU citizens (employees and self-employed persons) has been broadened. People falling into this category already had the right to take up residence in other EU member countries. Nonetheless, permanent right of residence after a stay of five years was only granted if the applicants had sufficient resources to ensure that social assistance will not be applied for in the future. The Directive has done away with this restriction. Gainfully employed Union citizens will be granted a right to permanent residence on the sole basis of five years of uninterrupted legal residence. They will have a right to the same welfare benefits which the host country provides to its own nationals.

In the following we examine the extent to which these measures provoke migration to those countries with the highest levels of welfare benefits. Since the Directive was not implemented in national laws and regulations until 2006, the answer to this question cannot be based on an ex-post analysis of migration flows. Rather, the approach pursued here is to quantify the incentives to migrate based on a number of model cases. In this article, Poland is taken as the country of origin and Germany as the host country.

\footnotetext{
* Wolfgang Ochel is senior researcher at the Ifo Institute for Economic Research at the University of Munich and CESifo Research Fellow. Gratitude is expressed to Wolfgang Meister and Martin Werding for valuable comments.
}

\section{Union citizens' right to move and reside freely in the $\mathbf{E U}$}

The right to free movement and residence in the EU has been considerably extended since its founding in 1957. At its inception, free movement was conceived of as an economic freedom. Workers were guaranteed freedom of movement and self-employed were guaranteed freedom of establishment. However, those not gainfully employed had no right to establish residence outside their own country. Since the beginning of the 1990s, the right to stay in another member country than one's own is no longer tied to participation in the economy. This was expressed clearly in the Directives on Free Movement and Residence of the early 1990s which provided, under certain conditions, a right of residence for students, retired persons and other inactive persons. In 1993, the Maastricht Treaty explicitly provided (in Article 18) that every Union citizen, whether gainfully employed or not, has the right to move and reside freely within the territory of Member States. The implementing regulations and the relevant decisions of the European Court were developed further and summarised in Directive 2004/38/EC (Hailbronner 2006).

The Directive provides for graduated regulations governing residence: no conditions are imposed on a Union citizen and his family members for residence in another member country other than valid identity papers for a period of up to three months. For a stay of between four to sixty months, a residence certificate is required. In order to obtain it, the Union citizen must establish his residence in the host country and register with the relevant authorities. At the end of five years of uninterrupted legal residence,,$^{1}$ the Union citizen is entitled unconditionally to permanent residence.

Granting a residence certificate for inactive Union citizens in the period between the fourth and the sixtieth month requires that they should have means of subsistence sufficient for the entire stay and that they should have adequate health insurance. These

${ }^{1}$ Temporary absence of up to six months in a year does not affect the continuity of residence.

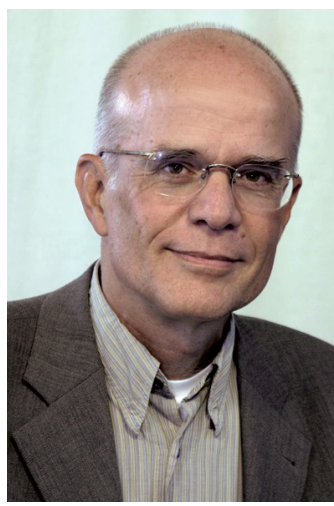


requirements are designed to ensure that social assistance will not be applied for. Health insurance coverage is considered to be adequate when it is - in the case of Germany - equivalent to statutory health insurance. Since access to statutory health insurance in Germany is subject to restrictive conditions (see Box 1), as a rule, foreigners from other EU countries will have to obtain health insurance from private insurers. Self-employed persons are entitled to a residence certificate, provided they exercise a gainful economic activity.

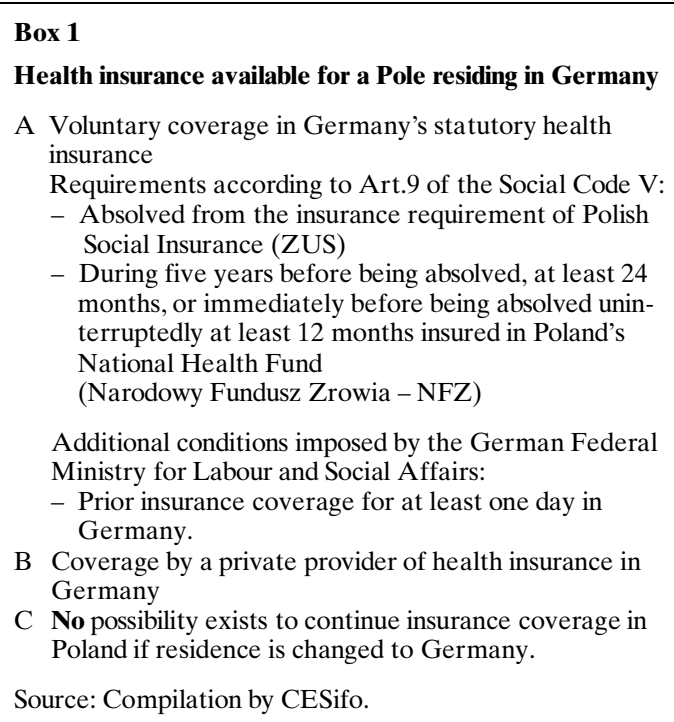

B Coverage by a private provider of health insurance in Germany

C No possibility exists to continue insurance coverage in Poland if residence is changed to Germany.

Source: Compilation by CESifo.

When a Union citizen registers in Germany, the registration office proceeds on the assumption that the requirements for residence are fulfilled if the person registering declares that they are. Unless there are prima facie grounds for doubt, no enquiries are instigated before issuing the certification requested. And in the ensuing five years no check on the fulfilment of the conditions for permanent residency is carried out unless the Union citizen applies for welfare benefits. In such a case the authority responsible for foreigners, after having been informed by the Social Assistance Office, can examine whether the requirements for residence continue to be fulfilled. In the case of an inactive Union citizen the required amount of means of subsistence should not exceed the threshold defined for social assistance for nationals. At the same time, no uniform amount for means of subsistence should be fixed. On the contrary, regional differences and the personal situation of the applicant must be taken into account. Merely claiming social assistance is not sufficient grounds for expulsion, but only laying a claim to excessively high benefits. What is excessive is, however, left unclear. Gainfully self-employed persons are required to exercise an independent activity.
The intensity with which this activity must be exercised is also not defined by law. It is, however, not necessary that the self-employed person should be able to cover his living expenses from the exercise of the activity completely.

\section{Access of Union citizens to the systems of social assistance of host countries}

As long as inactive EU citizens had no right to take up residence in other member countries, they could not claim welfare benefits in those countries. The extension of the right of free movement to them, however, has changed the situation radically (see Box 2):

- During a stay of less than three months, inactive Union citizens are not entitled to social assistance. Parity with citizens of the host country is not provided.2

- During a stay lasting between four and sixty months, inactive Union citizens are as a matter of principle entitled to welfare benefits, although the requirement of sufficient resources and adequate health insurance coverage is designed to ensure that this entitlement remains theoretical. In case the resources are exhausted sooner than expected or when health insurance coverage is not adequate, then the Social Assistance Offices grant benefits even though the conditions for residence are not fulfilled. If the host country wants to avoid this, the Union citizen's stay must be brought to an end (Sander 2005, 1016). As set out above, this involves an examination by the authority responsible for foreigners as to whether the claims to welfare were inappropriate.

- After a stay of five years, the Union citizen is entitled to the same welfare benefits as those the host country provides to its own nationals.

Gainfully self-employed persons who reside legally in Germany are entitled from the very beginning of their stay to welfare benefits (as a rule, unemployment benefit II which also may supplement own income). During the first five years of their stay, however, the authority responsible for foreigners is authorised to examine whether the conditions for continued residence are still fulfilled (see Box 2). At the end of the five years legal residence the Union citizen has a right to all welfare benefits.

${ }^{2}$ Nonetheless, Article 14 (1) of the Directive does not fully exclude claiming welfare benefits. 


\begin{tabular}{|c|c|c|}
\hline \multicolumn{3}{|c|}{ Entitlements of Union citizens to welfare benefits of the host country } \\
\hline \multirow{2}{*}{ Phase of stay } & \multicolumn{2}{|l|}{ Rule } \\
\hline & Inactive persons & Self-employed persons \\
\hline \multirow{2}{*}{$\begin{array}{l}1-3 \text { months } \\
4-60 \text { months }\end{array}$} & No entitlement & \multirow[b]{2}{*}{$\begin{array}{l}\text { A fundamental entitlement to welfare benefits exists } \\
\text { since the beginning of residence, but the presence of } \\
\text { income from economic activity should render this enti- } \\
\text { tlement theoretical. } \\
\text { If need is advanced, welfare benefits will be granted; } \\
\text { they may supplement income; at the same time it will } \\
\text { be examined whether the requirements for rights of } \\
\text { residence are still fulfilled (adequate economic activity); } \\
\text { the intensity with which this activity must be exercised } \\
\text { is not defined by law and will later on be determined by } \\
\text { decisions of courts; if conditions are not met, the resi- } \\
\text { dence certificate may be cancelled. }\end{array}$} \\
\hline & $\begin{array}{l}\text { As a matter of principle, an entitlement to } \\
\text { welfare benefits exists, but the requirement that } \\
\text { the Union citizen has sufficient resources and } \\
\text { health insurance coverage is designed to ensure } \\
\text { that in practical terms this entitlement will not } \\
\text { become relevant. } \\
\text { In the event that the citizen becomes needy, } \\
\text { welfare benefits will be provided; at the same } \\
\text { time, the conditions for continued residence will } \\
\text { be examined and expulsion may possibly be } \\
\text { ordered. }\end{array}$ & \\
\hline $\begin{array}{l}\text { Five years or } \\
\text { longer }\end{array}$ & \multicolumn{2}{|c|}{$\begin{array}{l}\text { Entitled to welfare benefits. } \\
\text { Union citizens are placed on an equal basis with citizens of the host country. }\end{array}$} \\
\hline
\end{tabular}

\section{Legal migration of inactive persons into welfare systems}

The Directive limits the incentives to migrate in that it restricts access to welfare benefits in the host country. The migrating EU citizen must reside in the host country during a five-year waiting period before he can claim welfare benefits. During this waiting period, the migrant must support himself out of his own resources and must pay health insurance premiums in the host country. In the case of inactive persons, income from employment is not relevant, and this means that changing residence to another EU country requires that the migrant should dispose of sufficient financial assets.

According to Borjas (1999) the migration incentives depend on the present discounted value of the net income differential, that is to say the difference of social security benefits $(S)$, which must exceed the costs of migration $(M C)$ plus the present discounted value of living expenses differential $(L E)$. Non-gainfully employed persons will decide to migrate from $\mathrm{O}$ (land of origin) to $\mathrm{H}$ (host country) if the condition in (1) is fulfilled, where $\mathrm{T}$ is the remaining life time and $r$ the discount rate. The living expenses include normal expenditure for subsistence plus health insurance premiums.

$$
\text { (1) } \int_{0}^{T} e^{-r t}\left\{S_{H}(t)-S_{O}(t)\right\} \mathrm{d} t>\int_{0}^{T} e^{-r t}\left\{L E_{H}(t)-L E_{O}(t)\right\} \mathrm{d} t+M C \text {. }
$$

Figure 1 describes the migration decision of a 60 year-old Pole who can claim old-age benefits in Poland upon reaching the age of 65 . In the upper panel, assets are represented on the vertical axis and time on the horizontal axis. Assets of the amount of $\mathrm{AB}$ are required in order to cover living expenses in Germany during the waiting period. ${ }^{3}$ In the case of a change of residence to Germany, the migrant's assets will decline as shown by the curve AE. At the point in time $\mathrm{E}$ they will be entirely exhausted. At the end of the five-year waiting period, our Pole is a pauper fulfilling the conditions for receiving welfare benefits just sufficient to cover his subsistence-level consumption.

If, however, our person had remained in Poland, he would only have used up part of his initial assets, since the cost of living would be lower and premiums for health insurance would be less. Thus in the case of non-migration only $\mathrm{CD}$ of his assets would be used up; at the end of five years he would still own assets amounting to DE.

In the lower panel of Figure 1, annual flows of income and costs that are relevant for the migration decision are shown graphically. They are converted at purchasing power parities. During the waiting period, total expenses associated with the stay in Germany amount to the area FHJM. This can be thought of as negative income. In Poland, on the other hand, the costs of living (including health insurance premiums) are lower (area FGJL). On balance, there is a difference in the expenditure for living expenses during the waiting period amounting to GHLM. After the waiting period there is no surplus of net income that compensates for this difference. The net income (Net IN: social security benefits - living expenses) in Germany is zero

${ }^{3}$ In the graphical presentation, the costs of migration are not considered. 
Figure 1

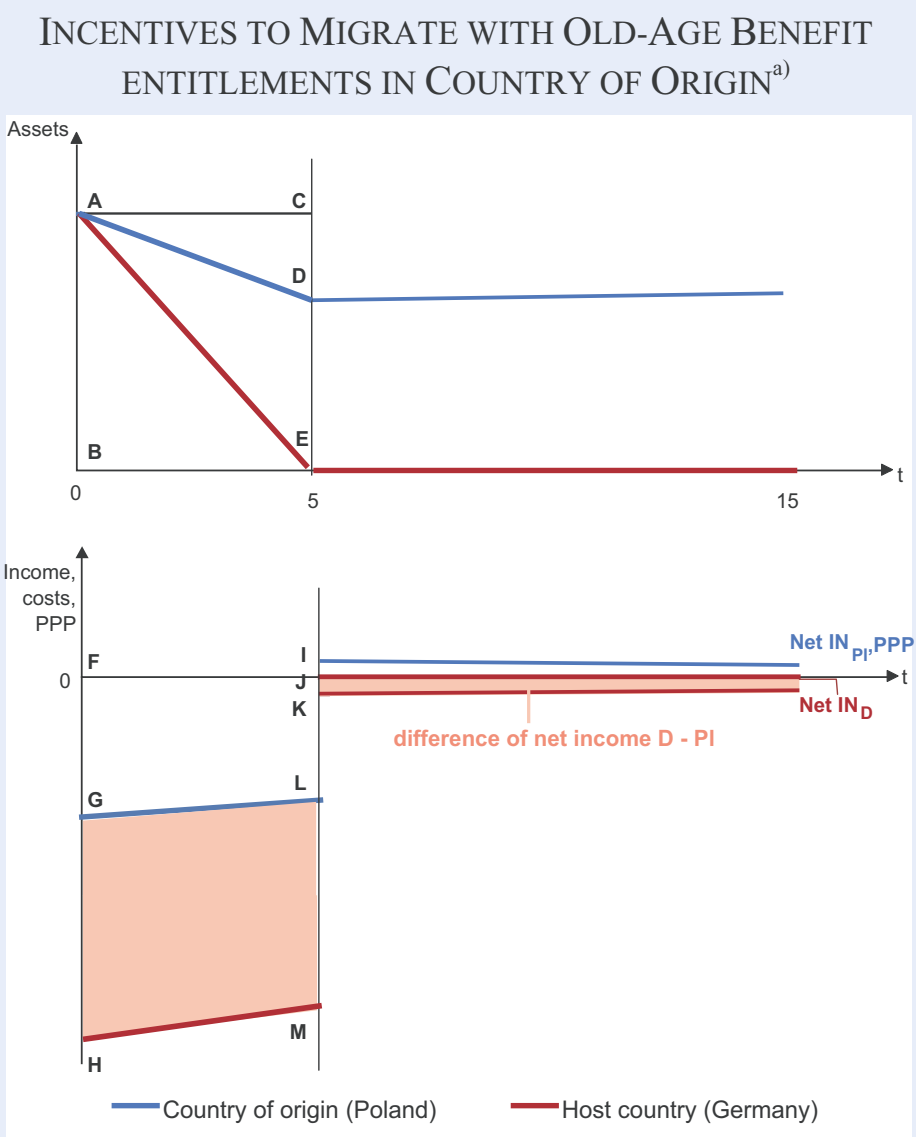

a) The incomes and costs in the graph are those for a single person.

Source: CESifo. cover the difference in living expenses as well as the direct migration costs (which are neglected in these calculations). In making this calculation, the streams of net income in Poland and Germany must be made comparable, i.e. the difference in the cost of living in the two countries must be taken into account. This has been done here by converting the stream of net income in Poland based on the purchasing power parity of the euro and the zloty. Table 1 shows present values of net incomes. The net income streams have been discounted by a nominal interest rate of 4.5 percent (real interest rate 3.0 percent, inflation rate 1.5 percent). Social assistance which could be claimed in Germany after the waiting period is compared to the old-age benefits which an average employee receives in Poland and the living expenses in the two countries. The comparison shows that starting at age 65 , a single person in Germany can expect within the next ten years whereas it is positive in Poland. Migration to Germany would not be financially attractive.

The scenarios illustrated above are based on calculations that are as realistic as possible. They are based on 2005 values. The decision to migrate requires that our Pole has adequate monetary resources, for he must be able to cover his living expenses in Germany during the first five years out of his own resources. A socio-culturally defined subsistence minimum must be met at all times. In Germany this is defined by the statutory rate for social assistance including subsidies for housing and heating costs of $€ 672$ per month for a single person and $€ 1,047$ for a couple without children as of July 2005. Moreover, he needs private health insurance with a monthly premium of $€ 600$ for a man or $€ 620$ for a woman. Given these hypotheses, a single person would need initial assets of $€ 71,876$; for a couple without children, the amount required would be $€ 128,100$ (Ochel 2007).

Apart from the possession of adequate assets, migration from Poland to Germany also depends on the expected gain in income that must be sufficient to a net income that is below his net income in Poland by $-€ 5,757$. For a couple without children, net income in Germany exceeds the corresponding figure in Poland by $€ 11,973$ which is however not enough to compensate for the difference in living expenses during the waiting period. In both cases, changing residence from Poland to Germany is not financially attractive.

Different results are obtained if one assumes a 40 year-old, non-gainfully employed Pole who in the foreseeable future has no expectations of old-age benefits and in case of need has only an entitlement to basic subsistence as defined in the Polish welfare system. In both cases (single person and couple without children) in year 12 the present value of the differences in income exceeds the present value of the differences in living expenses. As long as the citizens considering to migrate expect to live beyond the age of 52 and to receive social assistance or unemployment benefit II in Germany, then migration from Poland to Germany would be financially attractive (Ochel 2007). 
Table 1

Financial incentives to migrate from Poland (PI) to Germany (D) for a non-gainfully employed Pole, in $€^{*}$ Year 2005 present values

\begin{tabular}{|c|c|c|}
\hline & $\begin{array}{l}\text { Single } \\
\text { person }\end{array}$ & $\begin{array}{c}\text { Couple, } \\
\text { no children }\end{array}$ \\
\hline \multicolumn{3}{|c|}{ Expenditure during the five year waiting period (year 1 to year 5 ) } \\
\hline (1) Living expenses in $D^{a}$ ) & 37,972 & 59,162 \\
\hline (2) Health insurance premiums in $\mathrm{D}^{\mathrm{b}}$ ) & & \\
\hline (3) Living e & 900 & \\
\hline (4) Health insurance premiums in Pl, $\mathrm{PPP}^{\mathrm{d})}$ & 7,478 & 51 \\
\hline (5) Difference in living expenses D - Pl (1 + $2-3-4)$ & 44,499 & 82,141 \\
\hline \multicolumn{3}{|l|}{ Income starting at the age of 65 (year 6 to year 15) } \\
\hline (6) Welfare benefits in $\mathrm{D}^{\text {a) }}$ & 0,610 & 94,432 \\
\hline (7) Living ex & 610 & \\
\hline (8) Old-age benefits in $\mathrm{Pl}, \mathrm{PPP}^{\mathrm{e}}$ & .520 & 0 \\
\hline (9) Living expenses in Pl, PPP ${ }^{\text {f }}$ & 31,763 & 49,493 \\
\hline (10) Difference in net income D - Pl (6-7)-(8-9) & $-5,757$ & 11,973 \\
\hline \multicolumn{3}{|c|}{ 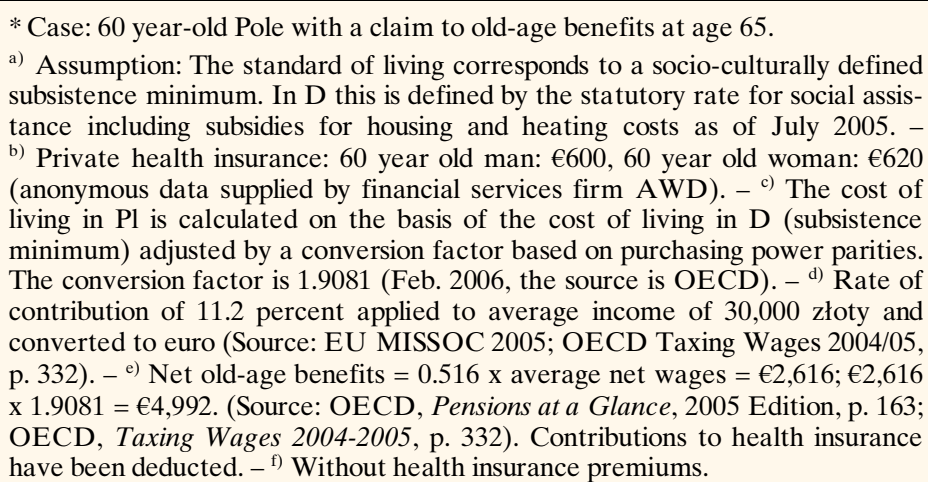 } \\
\hline
\end{tabular}

order to show fulfilment of the requirements. Nonetheless, the migrant will as a rule have to cover his living expenses and health insurance premiums out of his own resources. If assets are not present, then the only way to do this is to work in the informal sector of the economy, which it goes without saying, is also illegal.

Figure 2 illustrates the migration decision. Initial assets amount to nil (not shown in the figure). During the waiting period, the Union citizen in Germany obtains wages from work in the informal sector which amount to living expenses and health insurance premiums so that his net income is zero. In Poland he receives wages from regular employment leading to a positive net income (area ABEF). After the waiting period is expired, the migrant in Germany can expect income from social assistance and from illegal work. In Poland, he goes on working regularly. At the point in time at which

\section{Illegal migration of inactive persons into welfare systems}

Up to now the focus has been on legal migration into the welfare state. Illegal migration might be an alternative. The conditions linked to the right of permanent residence can, however, be circumvented only in part. Establishing residence in the host country and taking out health insurance are absolutely indispensable requirements. With a view to reducing the costs of living during the waiting period, a Union citizen could continue to live in his land of origin, whilst giving the registration office of the "host" country pro forma an address of a relative or a friend. This manoeuvre would, however, only be practicable if travel costs are not too high. It is in any case illegal and hence involves risks.

The Directive imposes the requirement that the migrant has adequate financial assets. If the Union citizen desirous of migrating has no assets, one can imagine that relatives or friends might be willing to place the required sum at his disposal temporarily in
DEHI>BCFG, migration becomes financially attractive.

In Germany, the income from illegal work must cover at least a socio-culturally defined subsistence minimum (that is to say, must at least equal social assistance, which is defined by such a standard); in addition, it must be sufficient to cover health insurance premiums. For a single person, $€ 55,489$ is sufficient to fulfil this requirement during the waiting period. The corresponding figures for a couple without children are $€ 98,716$. If one assumes that our immigrants would earn an average wage in Poland, then the difference in net income between Germany and Poland becomes $-€ 25,644$ for the single person and $-€ 43,152$ for the childless couple.

At the end of the waiting period, our immigrant to Germany can expect to receive social assistance or unemployment benefit II. Since welfare benefits minus living expenses in Germany are, on purchasing power terms, less than the net income of an average Polish employee, migration to Germany would 
Figure 2

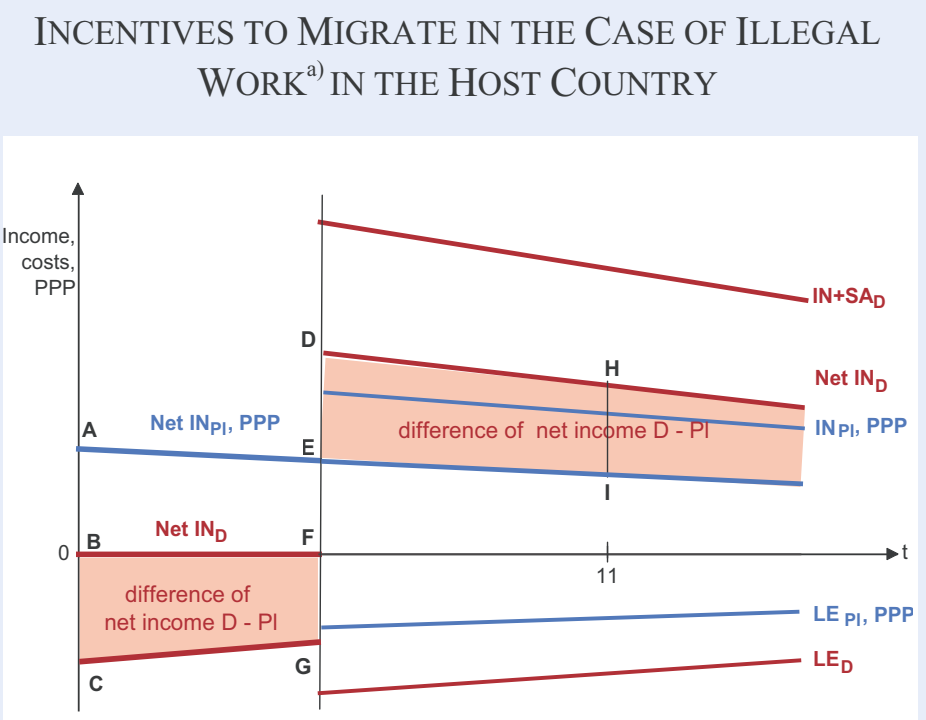

Country of origin (Poland) - - Host country (Germany)

IN: Income; LE: Living expenses; Net IN: Net income (income-costs);

SA: Social assistance.

a) The incomes and costs in the graph are those for a single person.

Source: CESifo.

not be financially attractive, unless the migrant goes on working in the informal sector after the waiting period is expired. In the latter case the present value of the net income received in Germany between year 6 and year 15 will be $€ 47,637$ more than in Poland for the single person and $€ 88,690$ more for a childless couple. For a stay in Germany of eleven, respectively ten, years and abstracting from migration costs changing residence to Germany is financially attractive. However, in the cases examined here, one must bear in mind the risk of not finding work in the informal sector, or the risk of being discovered in an illegal job (Ochel 2007).

\section{Legal migration of self-employed persons into welfare systems}

The Directive has broadened the right of residence of self-employed persons. Permanent right of residence after a stay of five years was, up to 2004 according to the Law of Residence of the EEC, only granted if the applicants had sufficient resources. The Directive has done away with this restriction. Self-employed Union citizens are granted a right to permanent residence on the sole basis of five years of uninterrupted legal residence and are entitled to welfare benefits.
As of 1 May 2004 the nationals and enterprises of the new member countries have the same rights of establishment in other member states as the nationals and enterprises of the old member countries. Restrictions on free movement of workers, which may be maintained for up to seven years, mean, however, that branches of enterprises from the new Member States (except for Malta and Cyprus) located in other EU countries are, except for key personnel, not allowed to employ people from their own country.

Freedom of establishment is understood as permitting the establishment of permanent economic activity in another member country. It includes the exercise of an independent economic activity as a self-employed person or the establishment and conduct of an enterprise. This independent economic activity may have the character of free-lance professional work, or commercial, trade or crafts activity.

With respect to a Pole desiring to establish himself as a tradesman in Germany, one must distinguish between trades requiring special qualification (e.g. possession of a master craftsman's certificate) and trades for which no special proof of qualification must be presented. Since the beginning of 2004, 41 craft trades (e.g. mason, plumber, joiner, baker) have been designated as requiring certification of qualification. If the Polish migrant has a qualification in his own country equivalent to the German master craftsman's qualification, then he may enrol in the register of qualified craftsmen in Germany. If the Polish migrant has no such formal qualification, he must have worked at least six years as a selfemployed person in the trade or as responsible head of a plant or workshop in Poland before he can exercise the craft in Germany. This period can be shortened to three years if a three year vocational training in the relevant craft can be documented or if the migrant has worked for at least five years as an employee in the relevant area. These periods must be certified by the competent Polish authorities. An other option for obtaining the right to exercise a 
craft in Germany is by passing a test (Art. 8 of the German Law Regulating the Conduct of Crafts and Trades).

For the 53 trades which may be exercised in Germany without any formal qualification, the migrants need not fulfil any requirements. These trades run from tilers and parquet-layers to building cleaning contractors or photographers. The same applies for the 57 areas of activity which are classified as being similar to craft trades.

Figure 3 illustrates the migration decision of a 40 year-old Pole who is self-employed. He needs to have initial assets sufficient to establish his business in the new location (not treated here as they may be relevant in Germany and Poland alike); no assets are required to cover living expenses and health insurance since it is assumed that the income needed to cover these will be earned in Germany. During the waiting period, our Union citizen will make a profit (P) out of his self-employed activity in Germany; for comparison the profits to be expected if he had remained in Poland are also shown. After the waiting period is expired, our individual may wish to continue his activity as a gainfully self-employed person. In the event that his business does not prosper, he can in case of need claim unemployment benefit II in Germany (UB II); in Poland the corresponding benefit would be social assistance (SA). The living expenses are shown by LE.
In Table 2, the income (in the form of profits) and the welfare benefit entitlements are compared. The comparison shows that a 40 year-old self-employed Pole will find it attractive to set up a business in Germany; this is equally true during the waiting period and afterwards. The financial incentives to migrate emanate both from better earning prospects and from more generous welfare benefits. For a 60 year-old Pole, migration is financially attractive too. However, a single person should return to Poland at the age of 65 , whereas a couple should remain in Germany.

Since April 2004 the German Association of Chamber of Crafts has collected statistics on the establishment of craft enterprises whose proprietors come from the EU-10 acceding countries. On 30 June 2006 there were 18,663 such enterprises in Germany; that corresponded to 2 percent of all craft enterprises in Germany (see Table 3). 97 percent of these enterprises are crafts that are not subject to proof of qualification or are quasi-crafts. Crafts requiring qualification equivalent to that of a master craftsman are, on the other hand, scarcely represented. Craft enterprises with owners from the acceding countries are concentrated in urban centres such as Berlin, Hamburg, Frankfurt and Munich. In the Federal States located near the borders to the new EU countries, there have been relatively few establishments (Hönekopp 2006).
Figure 3

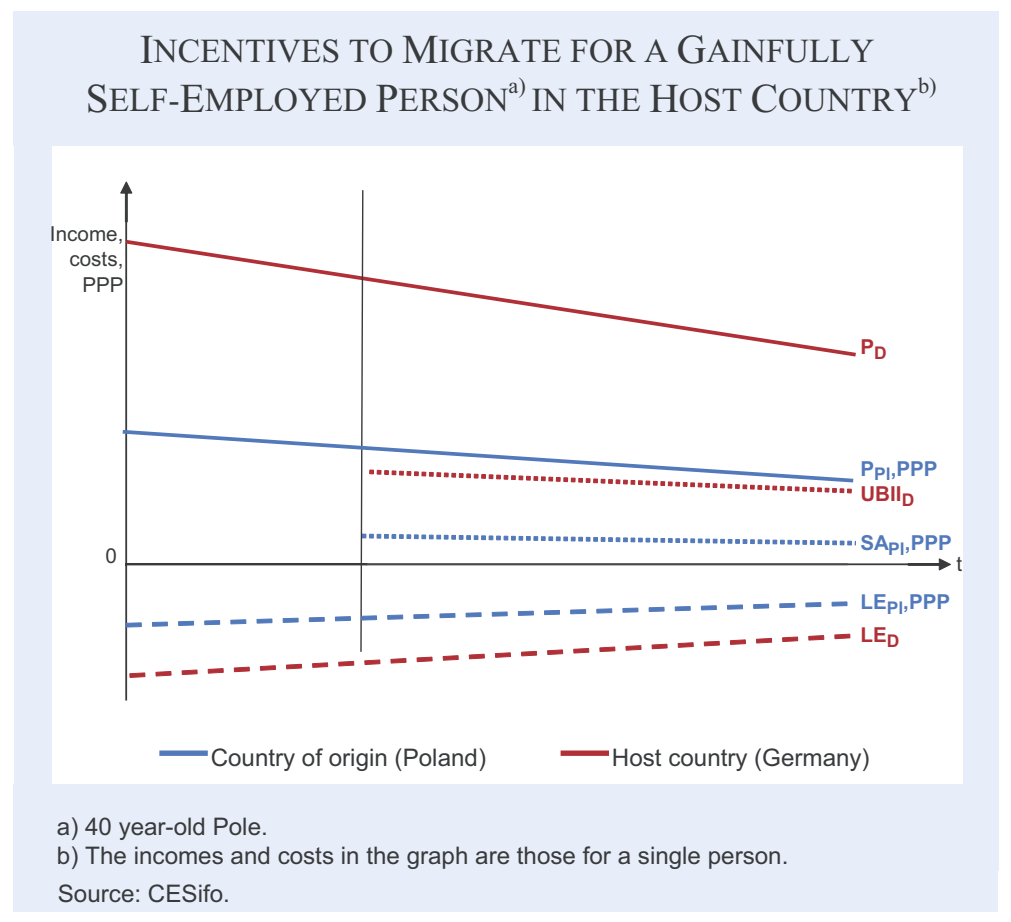

Summary and conclusions

Since the beginning of the 1990s, the restrictions on the freedom of movement and choice of residence of EU citizens have been progressively lifted. The Directive which went into force in 2004 laid down new and more liberal rules for movement across borders and for taking up residence in another EU country. Access to welfare benefits in host countries was made easier, although it continued to be tied to certain requirements (Sinn 2004).

The question arises as to what extent these new regulations will provoke migration within the EU from the less developed countries 
Table 2

Financial incentives for a Pole taking up self-employment in Germany (D) in $€$

Year 2005 present values

\begin{tabular}{|c|c|c|c|}
\hline & & $\begin{array}{l}\text { Single } \\
\text { person }\end{array}$ & $\begin{array}{l}\text { Couple, no } \\
\text { children }\end{array}$ \\
\hline \multicolumn{4}{|c|}{ Net income during the waiting period (year 1 to year 5 ) } \\
\hline (1) & Income in $\mathrm{D}^{\mathrm{a})}$ & 112,740 & 175,548 \\
\hline (2) & Living expenses in $\mathrm{D}^{\mathrm{b})}$ & 37,972 & 59,162 \\
\hline (3) & Net income in D (1-2) & 74,768 & 116,386 \\
\hline (4) & Income in $\mathrm{Pl}, \mathrm{PPP}^{\mathrm{a})}$ & 45,544 & 74,174 \\
\hline (5) & Living expenses in $\mathrm{Pl}, \mathrm{PPP}^{\mathrm{b})}$ & 19,900 & 31,022 \\
\hline (6) & Net income in Pl, PPP (4-5) & 25,644 & 43,152 \\
\hline (7) & Difference of net income D-Pl (3-6) & 49,124 & 73,234 \\
\hline \multicolumn{4}{|c|}{ Income after the waiting period (year 6 to year 15) } \\
\hline \multicolumn{4}{|c|}{ - Pole 45 years old - } \\
\hline (8) & Income in $\mathrm{D}^{\mathrm{a})}$ or & 179,950 & 278,605 \\
\hline (9) & Unemployment benefit II in $\mathrm{D}^{\mathrm{c})}$ & 60,610 & 94,432 \\
\hline (10) & Living expenses in $\mathrm{D}^{\mathrm{b})}$ & 60,610 & 94,432 \\
\hline (11) & Income in $\mathrm{Pl}, \mathrm{PPP}^{\mathrm{a})}$ or & 72,695 & 118,393 \\
\hline (12) & Social assistance in $\mathrm{Pl}, \mathrm{PPP}^{\mathrm{d})}$ & 18,587 & 18,587 \\
\hline \multirow[t]{2}{*}{ (13) } & Living expenses in $\mathrm{Pl}, \mathrm{PPP}^{\mathrm{b})}$ & 31,763 & 49,493 \\
\hline & - Pole 65 years old - & & \\
\hline (14) & Social assistance in D $(\mathrm{DFM})^{\mathrm{e})}$ & 60,610 & 94,432 \\
\hline (15) & Social assistance in $D(L R)^{\mathrm{f})}$ & 0 & 0 \\
\hline (16) & Living expenses in $\mathrm{D}^{\mathrm{b})}$ & 60,610 & 94,432 \\
\hline (17) & Old-age benefits in Pl, PPP & 37,520 & 37,520 \\
\hline (18) & Living expenses in $\mathrm{Pl}, \mathrm{PPP}^{\mathrm{b})}$ & 31,763 & 49,493 \\
\hline \multicolumn{4}{|c|}{$\begin{array}{l}\text { a) Hypothesis: Profits of self-employed (after taxes and deduction of health } \\
\text { insurance premiums) correspond to the average net income of employees. } \\
\text { Source: OECD Taxing Wages } 2004-2005 .-{ }^{\text {b) }} \text { See Table } 1 .-{ }^{c)} \text { In Germany, } \\
\text { self-employed who become unemployed do not receive unemployment bene- } \\
\text { fit I. - d) In Poland, social assistance is at most } € 108 \text { per month and house- } \\
\text { hold. Source: EU MISSOC Tables } 2006 .{ }^{\text {e) }} \text { Under the Directive (DFM). - } \\
\text { f) Under the Law of Residence of the EEC (LR). }\end{array}$} \\
\hline
\end{tabular}

Source: CESifo.

to the more developed countries. Since the Directive was not implemented in the member countries until 2006, it is impossible to provide an answer to this question based on an ex-post analysis. Instead, calculations have been made of the financial incentives to migrate in a number of model cases. The countries studied were Poland as the country of origin of the migrants, and Germany as the host country. Since welfare benefits are more generous in Germany, migration into German welfare systems is to be expected. However, the rules and regulations in force impose a waiting period of five years, which must first be bridged. This in turn means that an inactive Polish citizen seeking access to Germany's welfare systems must have at the beginning considerable financial assets. Only few Poles are able to fulfil this requirement. Then too, these persons must be prepared to liquidate these assets during the waiting period with a view to obtaining later welfare benefits in Germany. This is fraught with risks for the mi- grant, e.g. the risk that he will die during the waiting period, or that there might be a subsequent modification of the rules and regulations in his disfavour.

Apart from the possession of adequate assets there should be a surplus of net income arising from migration. To the extent that after the waiting period there is an entitlement to old-age benefits in Poland, then on a purchasing power parity basis the net income in Poland will exceed the net income to be expected in Germany: there is no financial incentive to migrate from Poland to Germany in such a case. If, however, the Polish citizen has to use up existing financial assets before he can put in a claim for social assistance - and this is in all likelihood the more general case - then there is indeed a financial incentive to migrate to Germany in order to take advantage of the more generous welfare benefits there.

If one considers persons who have no financial assets and who are capable of working, then the calculations show that migration is attractive assuming that they work in Germany in the informal sector; at the expiration of five years, they expect to also receive social assistance or unemployment benefit II. This option is, however, illegal and pursuing it involves considerable risks.

Another option is to exercise an activity as a selfemployed person. This is financially attractive too. The financial incentives emanate both from better earning prospects and from more generous welfare benefits. On June 2006 there were 18,663 craft enterprises in Germany whose proprietors came from the EU-10 acceding countries. That corresponds to two percent of all craft enterprises in Germany.

This analysis focuses on financial incentives. However, the social sphere, language and cultural differences between the countries under consideration are also important for the decision to migrate. Then too, individual factors such as life expectancy, 
Table 3

Craft enterprises in Germany whose owners come from one of the EU-10 acceding countries (as of $30 \mathrm{June} 2006$ )

\begin{tabular}{|c|c|c|c|}
\hline \multirow[t]{2}{*}{ Federal State } & \multirow[t]{2}{*}{$\begin{array}{l}\text { Total number } \\
\text { of enterprises }\end{array}$} & \multicolumn{2}{|c|}{$\begin{array}{l}\text { Enterprises whose own } \\
\text { ers come from one of } \\
\text { the EU-10 acceding } \\
\text { countries }^{\text {a) }}\end{array}$} \\
\hline & & Share in \% & Number \\
\hline Baden-Württemberg & 125,731 & 1.0 & 1,197 \\
\hline Bavaria & 179,051 & 2.1 & 3,764 \\
\hline Berlin & 33,113 & 6.2 & 2,050 \\
\hline Brandenburg & 37,060 & 1.0 & 375 \\
\hline Bremen & 4,966 & 2.3 & 113 \\
\hline Hamburg & 13,800 & 6.2 & 851 \\
\hline Hesse & 66,324 & 6.0 & 4,009 \\
\hline Lower Saxony & 78,743 & 2.3 & 1,775 \\
\hline Mecklenburg-Western Pomerania & 19,355 & 0.3 & 58 \\
\hline North Rhine-Westphalia & 172,405 & 1.6 & 2,825 \\
\hline Rhineland Palatinate & 47,558 & 1.8 & 850 \\
\hline Saarland & 11,390 & 0.6 & 73 \\
\hline Saxony & 56,869 & 0.5 & 303 \\
\hline Saxony-Anhalt & 29,289 & 0.1 & 25 \\
\hline Schleswig-Holstein & 28,815 & 1.2 & 360 \\
\hline Thuringia & 30,940 & 0.1 & 35 \\
\hline Federal Republic & 935,409 & 2.0 & 18,663 \\
\hline
\end{tabular}

Source: German Association of Chamber of Crafts, Establishment registration statistics; calculations of CESifo.
Sander, F. (2005), "Die Unionsbürgerschaft als Türöffner zu mitgliedstaatlichen Sozialversich egungen anlässlich des Trojani-Urteils des EuGH", Deutsches Verwaltungsblatt (DVBL), 1014-22.

Sinn, H.-W. (2004), "Freizügigkeitsrichtlinie: Freifahrt in den Sozialstaat", ifo Standpunkt 53.

life plan and the evaluation of risk influence the individual Union citizen's migration decision.

A number of years will have to pass before the effects on the migration into the welfare systems of individual EU member countries arising from the Directive will be known empirically. But it is already possible to say that in enacting the Directive the European lawmakers have undergone a considerable risk. Access to welfare systems has not been cut off but only made difficult by imposing certain conditions. In view of the still rudimentary nature of the financial compensation framework within the EU, it is entirely possible that the freedom of movement that has been accorded will impose excessive demands on the solidarity of Union citizens in the host countries.

\section{References}

Borjas, G. J. (1999), "The Economic Analysis of Immigration", in O. Ashenfelter and D. Card, eds., Handbook of Labor Economics, Vol. 3 A, Amsterdam, 1697-1760.

Hailbronner, K. (2006), "Union Citizenship and Social Rights", in J.-Y. Carlier and E. Guild, eds., The Future of Free Movement of Persons in the EU, Bruyland, Bruxelles, 65-78.

Hönekopp, E. (2006), "Germany”, in K. Tamas and R. Münz, eds., Labour Migrants Unbound? EU Enlargement, Transitional Measures and Labour Market Effects, Institute for Future Studies, Stockholm, 126-48.

Ochel, W. (2007), "The Free Movement of Inactive Union Citizens in the EU - A Challenge for the European Welfare State?", CESifo Working Paper, forthcoming. 